\title{
Senyawa Turunan Terpenoid dari Ekstrak Aseton Daun Perepat (Sonneratia alba) dan Aktivitasnya Terhadap Escherichia coli
}

\section{Terpenoid Derivative Compound from Acetone Extract of Perepat Leaves (Sonneratia alba) and Its Activity Against Escherichia coli}

\author{
Muhaimin $^{1, *}$, Kurnia Nastira Ningsih ${ }^{2}$, dan Madyawati Latief ${ }^{2}$ \\ ${ }^{1}$ Departemen Biologi Farmasi, Fakultas Farmasi Universitas Padjadjaran, \\ Jl. Bandung-Sumedang KM 21. Jatinangor, Sumedang, 45363 \\ 2 Program Studi Kimia Fakultas Sains dan Teknologi Universitas Jambi, \\ Jl. Jambi-Ma. Bulian KM 15 Mendalo Darat Jambi 36361
}

\begin{abstract}
A B S T R A K
Perepat (Sonneratia alba) secara tradisional masih digunakan untuk pengobatan luka, diare dan demam. Diare disebabkan oleh Escherichia coli. Daun perepat mengandung alkaloid, fenolat, triterpenoid, flavonoid, tanin, saponin, steroid dan glikosida. Terpenoid berpotensi sebagai antibakteri. Penelitian ini bertujuan untuk isolasi senyawa turunan terpenoid dan uji aktivitasnya terhadap Escherichia coli. Proses isolasi dilakukan dalam 3 tahap yaitu kromatografi vakum cair, kromatografi kolom gravitasi pertama dan kromatografi kolom gravitasi kedua. Isolat F2.2.2 murni sebagai kristal putih tajam. Titik leleh isolat F2.2.2 pada $210,2-211,{ }^{\circ} \mathrm{C}$. Hasil spektrofotometer UV-Vis memiliki serapan maksimum pada $203 \mathrm{~nm}$ dan $212 \mathrm{~nm}$ yang menunjukkan adanya transisi elektron $\pi \rightarrow \pi^{*}$ yang menunjukkan adanya gugus kromofor yang khas pada sistem ikatan rangkap $\mathrm{C}=\mathrm{C}$ terisolasi. Hasil interpretasi data FTIR menunjukkan senyawa memiliki gugus -OH $\left(3277,20 \mathrm{~cm}^{-1}\right),-\mathrm{C}-\mathrm{O}\left(1047,39 \mathrm{~cm}^{-1}\right),-\mathrm{C}=\mathrm{C}$ terisolasi $\left(1656,92 \mathrm{~cm}^{-1}\right),-$ C-H alifatik $\left(2896,24 \mathrm{~cm}^{-1}\right)$ dan gem dimetil $\left(1463,07 \mathrm{~cm}^{-1}\right.$ dan $\left.1377,23 \mathrm{~cm}^{-1}\right)$ sebagai karakteristik senyawa triterpenoid. Berdasarkan hal tersebut diduga isolat F2.2.2 merupakan senyawa turunan triterpenoid lupan yaitu Lupeol. Hasil uji aktivitas antibakteri terhadap Escherichia coli menunjukkan bahwa ekstrak aseton daun perepat memiliki aktivitas yang lemah, sedangkan isolat F2.2.2 tidak memiliki aktivitas.
\end{abstract}

\section{A B S T R A C T}

Perepat (Sonneratia alba) is traditionally still used for the treatment of wounds, diarhea and fever. Diarhea is caused by Escherichia coli. Perepat leaves contain alkaloids, phenolics, triterpenoids, flavonoids, tannins, saponins, steroids and glycosides. Terpenoids have potential as antibacterial activity. This study aims to isolate terpenoid derived compound and test its activity against Escherichia coli. Isolation process was carried out in 3 stages that are liquid vacuum chromatography, first gravity column chromatography and second gravity column chromatography. The pure F2.2.2 isolate as sharp white crystals. The melting point of F2.2.2 isolate at $210.2-211.1{ }^{\circ} \mathrm{C}$. The results of the UVVis spectrophotometer have maximum absorption at $203 \mathrm{~nm}$ and $212 \mathrm{~nm}$ indicating the existence of an electron transition $\pi \rightarrow \pi^{*}$ which indicates the presence of a chromophore group which is typical for double bond system of isolated $C=C$. Interpretation results of FTIR data indicate compound have -OH groups $\left(3277.20 \mathrm{~cm}^{-1}\right),-C-O(1047.39$ $\left.\mathrm{cm}^{-1}\right),-C=C$ isolated $\left(1656.92 \mathrm{~cm}^{-1}\right),-C-H$ aliphatic $\left(289.24 \mathrm{~cm}^{-1}\right)$ and gem dimethyl $\left(1463.07 \mathrm{~cm}^{-1}\right.$ and $1377.23 \mathrm{~cm}^{-}$ $\left.{ }^{1}\right)$ as the characteristic triterpenoid compounds. Based on that, it is estimated that F2.2.2 isolate is a triterpenoid lupan derivative compound, namely Lupeol. The results of the antibacterial activity test on Escherichia coli showed that acetone extract of perepat leaves had weak activity, whereas F2.2.2 isolate had no activity.

Kata kunci/keyword $\quad$ : Perepat, Terpenoids, UV-Vis, FTIR, Antibakterial, Escherichia coli

I N F O A R T I K E L

Received: 04 Apr 2021;

* coresponding author: muhaimin@, unpad.ac.id

Revised: 09 July 2021;

DOI: https://doi.org/10.22437/jisic.v13i2.14714

Accepted: 10 September 2021 


\section{PENDAHULUAN}

Indonesia merupakan negara yang memiliki area hutan mangrove terluas di dunia dengan luas 3,5 juta ha. Di Pulau Sumatera, luas kawasan hutan mangrove sekitar 673.300 ha (Yudasakti et al., 2014). Salah satu provinsi di pulau Sumatera yang memiliki kawasan banyak terdapat mangrove adalah Provinsi Jambi tepatnya di Kabupaten Tanjung Jabung Timur, dengan jenis mangrove yang banyak ditemui adalah Perepat (Sonneratia alba). Mangrove dapat hidup di daerah yang ekstrim dikarenakan adanya senyawa yang melindunginya dari kerusakan, sehingga mangrove memiliki potensi yang besar untuk dijadikan sumber senyawa metabolit sekunder.

Uji fitokimia terhadap bagian daun perepat menunjukkan terdapat kandungan metabolit sekunder berupa alkaloid, fenolik, triterpenoid, flavonoid, tanin, saponin (Latief et al., 2014), steroid dan glikosida (Surya dan Hari, 2017). Pada bagian kulit batang telah ditemukan dua senyawa triterpenoid lupan, lupan-3b-ol dan lupeol (Harizon et al., 2014).

Ekstrak dan bahan mentah dari perepat secara tradisional masih banyak dimanfaatkan oleh masyarakat pesisir Indonesia untuk pengobatan luka, diare, dan demam (Noor et al., 2006). Diare merupakan penyakit yang disebabkan oleh bakteri Escherichia coli, sehingga kemampuan perepat sebagai obat diare menunjukkan adanya aktivitas sebagai antibakteri terhadap Escherichia coli. Penelitian mengenai aktivitas antimikroba dari daun perepat menunjukkan memiliki aktivitas terhadap bakteri Staphylococcus aureus, Bacillis cereus, Escherichia coli dan jamur Cryptococcus neoformans (Saad et al., 2012) serta bakteri Proteus vulgaris dan Proteus mirabilis (Sahoo et al., 2012).

Salah satu golongan senyawa metabolit sekunder yang memiliki aktivitas antibakteri adalah terpenoid. Terpenoid dapat bereaksi dengan porin (protein transmembran) pada membran luar dinding sel bakteri sehingga mengakibatkan rusaknya porin (Cowan, 1999). Penelitian oleh Djoukeng et al. (2005) terhadap tumbuhan Syzygium guineense juga menunjukkan bahwa senyawa triterpenoid berupa asam arjulonat dan asam asiatat memiliki aktivitas antibakteri yang sangat signifikan dalam menghambat pertumbuhan bakteri Escherichia coli, Bacillus subtilis dan Shigella sonnei.

Kemampuan perepat (Sonneratia alba) sebagai obat diare menunjukkan adanya aktivitas antibakteri terhadap Escherichia coli. Bagian daun perepat diketahui mengandung senyawa golongan terpenoid yang berpotensi sebagai antibakteri, akan tetapi belum dilakukan isolasi dan uji aktivitas antibakterinya. Terpenoid bersifat semipolar sehingga dapat diekstraksi menggunakan pelarut semipolar seperti aseton. Oleh karena itu, pada penelitian dilakukan isolasi senyawa turunan terpenoid menggunakan ekstrak aseton serta uji aktivitas antibakteri dari ekstrak dan isolat terhadap Escherichia coli.

\section{METODOLOGI PENELITIAN}

\section{Bahan Penelitian}

Bahan dalam penelitian ini adalah daun perepat (Sonneratia alba), aseton, nheksana, etil asetat, metanol, plat Kromatografi Lapis Tipis, aquades, $\mathrm{H}_{2} \mathrm{SO}_{4}$ 2N, Pereaksi Dragendorff, Pereaksi Meyer, $\mathrm{HCl}$ pekat, serbuk $\mathrm{Mg}, \mathrm{HCl} 2 \mathrm{~N}, \mathrm{FeCl}_{3}$, kloroform, Pereaksi Liebermann-Burchard (anhidrida asetat dan asam sulfat pekat), paper disc, Nutrient Agar (NA), silika gel dan alkohol $70 \%$. Kontrol positif dan kontrol negatif pada pengujian antibakteri adalah kloramfenikol $0,3 \%$ dan pelarut aseton.

\section{Peralatan Penelitian}

Alat yang digunakan selama penelitian yaitu Rotary Evaporator, pompa vakum, kolom kromatografi, peralatan gelas, plat tetes, kaca arloji, inkubator, Laminar Air Flow, autoklaf, timbangan analitik, pipet tetes, pipet ukur, tabung reaksi, cawan petri, kawat ose, botol vial, pipa kapiler, bunsen, detektor UV, Melting Point Apparatus, Spektrofotometer UV-Vis Merk Agilent Technologies Cary 60 UV-Vis dan Spektrofotometer FTIR Merk SHIMADZU IRPrestige-21. 


\section{Ekstraksi}

Daun perepat segar dibersihkan, dipotong kecil-kecil dan dikeringkan selama beberapa hari. 572 gram sampel daun perepat kering dimaserasi dengan pelarut aseton (semipolar) selama 3 hari dan dilakukan 2 kali pengulangan. Maserat yang diperoleh dipekatkan dengan rotary evaporator, kemudian diuapkan pelarutnya sampai didapat ekstrak aseton pekat.

\section{Isolasi Senyawa}

Kromatografi kolom vakum cair (KVC) menggunakan fase diam silika gel dengan perbandingan sampel:silika gel (1:20). Ekstrak diimpregnasi dengan silika gel kasar, kemudian ditambahkan ke dalam kolom yang telah berisi fase diam. Sedangkan fase gerak yang digunakan yaitu n-heksana:etil asetat dan etil asetat:metanol dengan variasi perbandingan $(10: 0 ; 9: 1 ; 8: 2$; $7: 3 ; 6: 4 ; 5: 5 ; 4: 6 ; 3: 7 ; 2: 8 ; 1: 9$ dan $0: 10)$. Fraksi yang diperoleh ditampung dalam botol vial, eluat yang ditampung berdasarkan tiap pita yang didapat kemudian diuapkan. Hasil dari kromatografi kolom dilakukan KLT kembali. Eluat yang memiliki pola noda identik digabungkan berdasarkan nilai $\mathrm{Rf}$ pada kromatogram. Fraksi yang masih memiliki banyak spot noda maka dilanjutkan pemisahan lagi menggunakan kromatografi kolom gravitasi (KKG). Eluat yang memiliki satu spot noda kemudian diuji menggunakan 3 jenis eluen berbeda, dimana jika hasil KLT tetap satu spot noda maka didapatkan isolat. Isolat dimurnikan dengan rekristalisasi menggunakan pelarut n-heksana dan etil asetat. Selanjutnya dilakukan skrining fitokimia dan uji titik leleh.

\section{Karakterisasi}

Spektrofotometer UV-Vis. $1 \mathrm{mg}$ isolat dilarutkan dalam $2 \mathrm{~mL}$ metanol, dimasukkan dalam kuvet dan diamati spektrumnya pada panjang gelombang 200$400 \mathrm{~nm}$.

Spektrofotometer FTIR. $1 \mathrm{mg}$ isolat dicampur dengan $50 \mathrm{mg}$ pelet $\mathrm{KBr}$, dihomogenkan kemudian diidentifikasi pada bilangan gelombang $4000-400 \mathrm{~cm}^{-1}$.

\section{Uji Aktivitas Antibakteri}

Larutan uji adalah ekstrak aseton daun perepat dengan konsentrasi 10; 50; 100; $500 ; 1000 \mu \mathrm{g} / \mathrm{mL}$ (ppm) dan isolat dengan konsentrasi 20; 40; 60; 80; $100 \mu \mathrm{g} / \mathrm{mL}$ (ppm) dalam pelarut aseton. Kontrol positif yang digunakan adalah kloramfenikol $0,3 \% \mathrm{w} / \mathrm{v}$ dalam pelarut aseton dan kontrol negatifnya adalah pelarut aseton. Peremajaan bakteri dilakukan menggunakan metode gores secara aseptik dan merata.

Paper disk dicelupkan ke dalam setiap larutan uji (ekstrak dan isolat), kloramfenikol sebagai kontrol positif dan aseton sebagai kontrol negatif, kemudian diletakkan pada permukaan media NA yang telah dilakukan peremajaan bakteri Escherichia coli sebelumnya. Selanjutnya diinkubasi pada temperatur $37^{\circ} \mathrm{C}$ selama 18 24 jam. Pengujian dilakukan secara duplo. Zona bening yang terbentuk kemudian diukur dengan menggunakan jangka sorong. Hasil zona hambat larutan uji dibandingkan dengan kontrol positif kloramfenikol. Aktivitas antibakteri terbesar ditunjukkan oleh luas diameter zona bening terbesar yang terbentuk.

\section{Analisis Data}

Analisis fitokimia berdasarkan reaksi antara reagen dengan sampel yang ditandai dengan perubahan warna, timbul endapan, terbentuk lapisan serta perubahan suhu.

Analisis UV-Vis dilakukan dengan melihat puncak maksimum pada panjang gelombang 200-400 nm. Analisis FTIR dilakukan dengan melihat bilangan gelombang dari spektrum sampel pada bilangan gelombang $4000-400 \mathrm{~cm}^{-1}$.

Analisis aktivitas antibakteri berdasarkan diameter zona bening yang terbentuk. Selanjutnya, dibandingkan dengan data literatur untuk menentukan kategori kekuatan aktivitas antibakterinya.

\section{HASIL DAN PEMBAHASAN}

Ekstraksi sampel menggunakan metode ekstraksi tunggal dengan pelarut aseton (semipolar) sebanyak beberapa kali pengulangan. Dari 572 gram sampel daun perepat kering diperoleh ekstrak aseton 
sebanyak 56,3378 gram atau \%rendemennya sebesar 9,8493\%. Hasil skrining fitokimia ekstrak aseton daun perepat dapat dilihat pada tabel 1:

Tabel 1. Hasil skrining fitokimia ekstrak aseton daun perepat (Sonneratia alba)

\begin{tabular}{lll}
\hline Uji fitokimia & Hasil & Keterangan $(+)$ \\
\hline Alkaloid & & \\
- Pereaksi Dragendorff & - & - Endapan merah hingga jingga \\
- Pereaksi Meyer & - & $\bullet$ Endapan putih kekuningan \\
Flavonoid & + & Terbentuk buih, warna jingga \\
Saponin & + & Busa yang stabil \\
Tanin & + & Warna hitam kehijauan \\
Steroid & + & Warna biru atau hijau \\
Triterpenoid & + & Warna ungu atau jingga \\
\hline
\end{tabular}

* Keterangan :

$(+)$ : Terdapat senyawa metabolit sekunder

(-) : Tidak terdapat senyawa metabolit sekunder

Berdasarkan data tabel 1 diketahui bahwa senyawa metabolit sekunder yang terdapat pada ekstrak aseton daun perepat yaitu golongan flavonoid, saponin, tanin, steroid dan triterpenoid sesuai dengan penelitian Siahaya et al. (2018).

\section{Isolasi Senyawa Turunan Terpenoid}

Isolasi senyawa dilakukan dalam 3 tahap yaitu kromatografi vakum cair (KVC), kromatografi kolom gravitasi (KKG) pertama dan kromatografi kolom gravitasi (KKG) kedua.

Tahap pertama yaitu pemisahan dengan kromatografi vakum cair (KVC) yang bertujuan untuk penyederhanaan senyawa yang ada di dalam ekstrak. Diperoleh 24 vial hasil KVC yang selanjutnya dianalisa dengan kromatografi lapis tipis (KLT) untuk penyatuan fraksi gabungannya. Diperoleh 4 fraksi gabungan yaitu vial 2-4 (fraksi 1), vial 5-12 (fraksi 2), vial 13-17 (fraksi 3) dan vial 18-24 (fraksi 4). Setelah digabungkan, dilakukan uji fitokimia terhadap keempat fraksi untuk mencari fraksi yang positif mengandung triterpenoid sehingga akan dilanjutkan ke tahap isolasi berikutnya. Hasil pengujian menunjukkan fraksi 2 (F2) yang positif pada uji triterpenoid dengan berubah warna menjadi jingga.

Tahap kedua yaitu pemisahan dengan kromatografi kolom gravitasi (KKG) yang

bertujuan untuk pemisahan lebih spesifik. Diperoleh 84 vial hasil KKG yang selanjutnya dianalisa dengan kromatografi lapis tipis (KLT) untuk penyatuan fraksi gabungannya. Diperoleh 4 subfraksi gabungan yaitu vial 10-13 (fraksi 2.1), vial 14-41 (fraksi 2.2), vial 42-59 (fraksi 2.3) dan vial 60-84 (fraksi 2.4). Dilakukan uji fitokimia terhadap keempat subfraksi dan subfraksi 2.2 (F2.2) menunjukkan hasil positif pada uji triterpenoid dengan berubah warna menjadi jingga.

Tahap ketiga yaitu pemisahan dengan kromatografi kolom gravitasi (KKG) lanjutan dikarenakan hasil KKG sebelumnya belum menunjukkan pola noda tunggal. Diperoleh 75 vial hasil KKG lanjutan yang kemudian dianalisa dengan kromatografi lapis tipis (KLT) untuk penyatuan fraksi gabungannya. Diperoleh 4 sub subfraksi gabungan yaitu vial 92-101 (fraksi 2.2.1), vial 102-103 (fraksi 2.2.2), vial 104-129 (fraksi 2.2.3) dan vial 130-159 (fraksi 2.2.4). F2.2.2 membentuk kristal yang masih kotor sehingga dilakukan pencucian dengan nheksana. Kristal putih berupa endapan berjarum yang tidak terlarut dalam n-heksana direkristalisasi dengan etil asetat untuk menghilangkan sisa pengotornya. Isolat F2.2.2 yang didapat sebanyak $12,6 \mathrm{mg}$. Uji fitokimia dengan pereaksi LiebermannBurchard menunjukkan perubahan warna menjadi jingga-kecoklatan sehingga isolat F2.2.2 positif merupakan senyawa golongan 
triterpenoid. Isolat F2.2.2 terlihat pada gambar 1 .

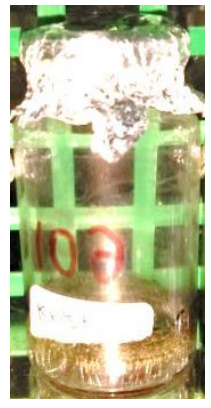

(a)

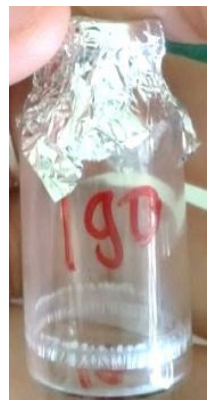

(b)
Gambar 1. Isolat F2.2.2 dari ekstrak aseton daun perepat (a) sebelum dicuci n-heksana (b) setelah dicuci nheksana

Berikutnya diuji kemurnian isolat F2.2.2 dengan cara KLT sistem 3 jenis eluen yang bertujuan agar campuran senyawa dengan tingkat kepolaran yang relatif sama akan dapat terpisahkan melalui salah satu sistem eluen yang digunakan. Hasilnya dapat dilihat pada gambar 2 .

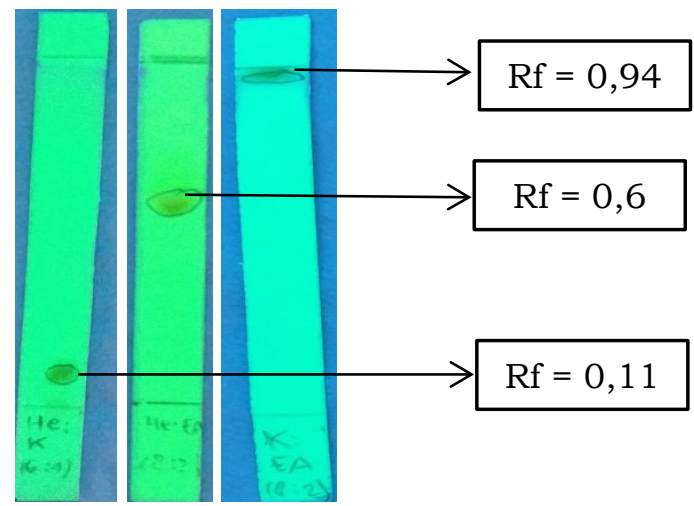

Gambar 2. Uji kemurnian KLT sistem 3 jenis eluen

\section{Keterangan :}

(I) n-Heksana : Kloroform (6:4)

(II) n-Heksana : Etil Asetat (8:2)

(III) Kloroform : Etil Asetat (8:2)

Dari hasil KLT isolat F2.2.2 menggunakan 3 jenis eluen dapat diketahui bahwa isolat telah murni dengan pola noda tunggal di setiap jenis eluen dengan nilai $\mathrm{Rf}$ 0,$11 ; 0,6$ dan 0,94 .
Titik leleh isolat F2.2.2 berada pada suhu $210,2-211,1^{\circ} \mathrm{C}$ (dalam rentang $0,9^{\circ} \mathrm{C}$ ). Hasil ini menunjukkan bahwa isolat F2.2.2 merupakan senyawa murni karena memiliki rentang suhu meleleh $1-2^{\circ} \mathrm{C}$ (Bell, 1997). Titik leleh isolat F2.2.2 menyerupai titik leleh Lupeol yaitu $210-211^{\circ} \mathrm{C}$ (Igoli dan Alexander, 2008).

\section{Karakterisasi Senyawa Hasil Isolasi}

Spektrum UV dari isolat F2.2.2 ekstrak aseton daun perepat dapat dilihat pada gambar 3.

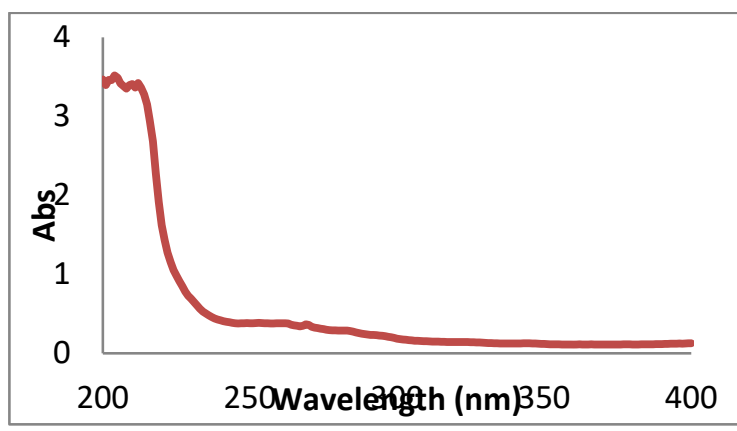

Gambar 3. Spektrum UV dari isolat F2.2.2 ekstrak aseton daun perepat

Spektrum UV (MeOH) pada gambar 3 menunjukkan serapan maksimum pada panjang gelombang $203 \mathrm{~nm}$ dan $212 \mathrm{~nm}$. Serapan maksimum pada $203 \mathrm{~nm}$ merupakan serapan cut off dari pelarut metanol $(\mathrm{MeOH})$ yang digunakan (Hartini et al., 2012). $\mathrm{MeOH}$ memiliki nilai UV cut off (nilai maksimal pelarut memberikan serapan UV) pada 205 $\mathrm{nm}$ sehingga umum digunakan sebagai pelarut untuk analisis senyawa organik (Gandjar dan Rohman, 2018). Pelarut $\mathrm{MeOH}$ menyebabkan serapan yang kuat terentang di daerah dekat UV, menghasilkan cut off dalam rentang 200-220 nm (Silverstain et al., 1981).

Serapan maksimum pada $212 \mathrm{~nm}$ menunjukkan adanya transisi elektron $\pi \rightarrow \pi^{*}$ yang mengindikasikan adanya gugus kromofor yang khas untuk sistem ikatan rangkap dari $\mathrm{C}=\mathrm{C}$ terisolasi. Suatu ikatan rangkap yang tidak terkonjugasi (terisolasi) seperti dalam etilen $(\mathrm{C}=\mathrm{C})$ mengabsorpsi pada $\lambda_{\text {maks }}$ kecil dari $200 \mathrm{~nm}$ (Dachriyanus, 2004). Adanya gugus auksokrom (substituen seperti -OH) akan memperlebar sistem kromofor dan menggeser absorpsi 
maksimum ke arah panjang gelombang yang lebih panjang (Roth dan Blaschke, 1985). Lupeol memiliki substituen -OH yang menyebabkan serapan maksimum ikatan rangkap $\mathrm{C}=\mathrm{C}$ nya bergeser ke arah yang lebih panjang yaitu $212 \mathrm{~nm}$. Lupeol menunjukkan serapan pada $\lambda_{\text {maks }}(\mathrm{MeOH}) 210 \mathrm{~nm}$ (Igoli dan Alexander, 2008). Berdasarkan data spektrum UV ini, senyawa hasil isolasi diduga berasal dari golongan triterpenoid; Lupeol.

Spektrum IR dari isolat F2.2.2 ekstrak aseton daun perepat dapat dilihat pada gambar 4.

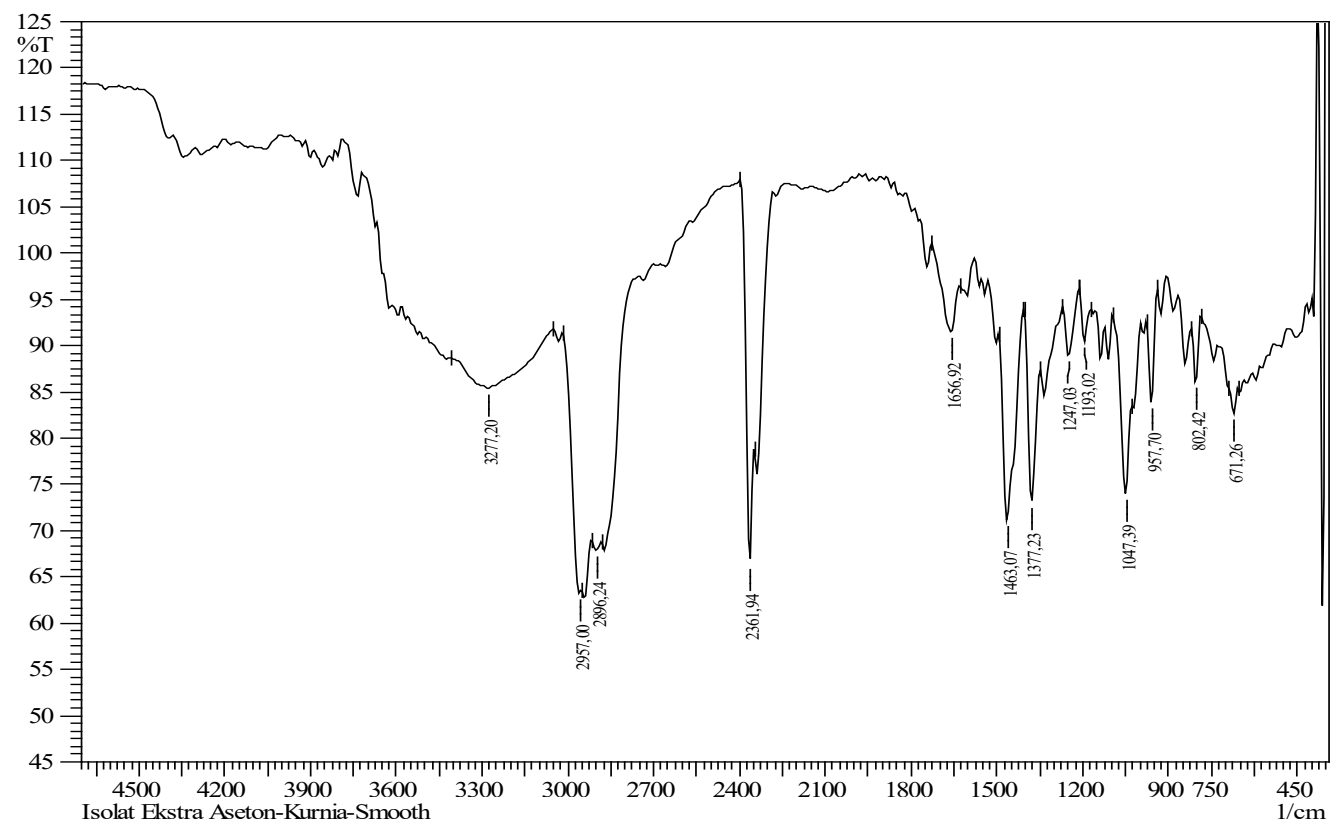

Gambar 4. Spektrum FTIR dari isolat F2.2.2 ekstrak aseton daun perepat

Spektrum FTIR isolat F2.2.2 (gambar 4) menunjukkan serapan pada bilangan gelombang $3277,20 \mathrm{~cm}^{-1}$ yang melebar sebagai gugus hidroksil $(-\mathrm{OH})$ dan didukung oleh serapan pada bilangan gelombang $1047,39 \mathrm{~cm}^{-1}$ sebagai vibrasi ulur ikatan C-O. Serapan pada bilangan gelombang 1656,92 $\mathrm{cm}^{-1}$ menunjukkan adanya ikatan rangkap terisolasi. Munculnya serapan pada bilangan gelombang 2896,24 $\mathrm{cm}^{-1}$ menunjukkan adanya vibrasi ulur ikatan $\mathrm{C}-\mathrm{H}$ (alkana) alifatik yang mengindikasikan adanya gugus metil $\left(\mathrm{CH}_{3}\right)$ dan metilena $\left(\mathrm{CH}_{2}\right)$ yang diperkuat dengan adanya gugus gem dimetil pada bilangan gelombang $1463,07 \mathrm{~cm}^{-1}$ dan $1377,23 \mathrm{~cm}^{-1}$.

Isolat F2.2.2 memiliki gugus $-\mathrm{OH}$, ikatan C-O, ikatan rangkap terisolasi, ikatan $\mathrm{C}-\mathrm{H}$ serta gugus gem dimetil. Keberadaan gugus gem dimetil yang merupakan ciri khas dari senyawa triterpenoid. Data spektrum FTIR isolat F2.2.2 memiliki kemiripan dengan data spektrum FTIR senyawa triterpenoid lupan; Lupeol, hasil penelitian Harizon et al. (2014) yang mengisolasi dari ekstrak etil asetat (semipolar) kulit batang Sonneratia alba dan hasil penelitian Muharni (2010) yang mengisolasi dari ekstrak metanol daun manggis hutan (Garcinia bancana Miq.).

Selain kemiripan data spektrum UV dan FTIR, isolat F2.2.2 juga menunjukkan bentuk isolat yang sama dengan Lupeol (hasil isolasi Harizon et al. (2014) dan Muharni (2010)) yaitu kristal berwarna putih berupa endapan berjarum. Dengan demikian, diperkirakan bahwa isolat F2.2.2 merupakan senyawa turunan triterpenoid lupan; Lupeol. Struktur senyawa Lupeol dapat dilihat pada gambar 5. 


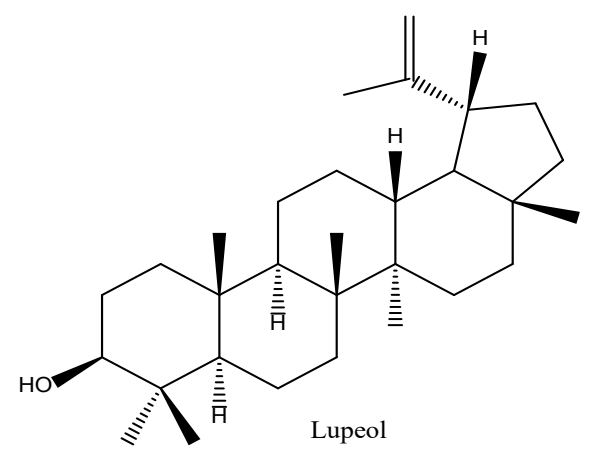

Gambar 5. Struktur senyawa triterpenoid lupan; Lupeol $\left(\mathrm{C}_{30} \mathrm{H}_{50} \mathrm{O}\right)$

\section{Uji Aktivitas Antibakteri Terhadap Escherichia coli}

Metode yang digunakan adalah metode difusi agar jenis metode cakram kertas (paper disc). Aktivitas penghambatan diindikasikan melalui zona bening yang muncul disekitar paper disc uji. Semakin besar diameter zona bening (zona hambat), maka semakin besar aktivitas antibakteri dikarenakan zona bening disekitar paper disc menunjukkan adanya aktivitas antibakteri (Pratama, 2005). Hasil uji aktivitas antibakteri disajikan pada tabel 2.

Tabel 2. Hasil pengukuran diameter zona hambat ekstrak dan isolat terhadap Escherichia coli

\begin{tabular}{ccccc}
\hline Sampel & $\begin{array}{c}\text { Konsentrasi } \\
(\mathbf{p p m})\end{array}$ & $\mathbf{1}$ & $\begin{array}{c}\text { Diameter zona bening } \\
(\mathbf{m} \mathbf{)})\end{array}$ & Rata-rata \\
\hline \multirow{5}{*}{ Ekstrak aseton } & 1000 & 2,0 & 2,0 & 2,0 \\
& 500 & 2,0 & 0 & 1,0 \\
& 100 & 0 & 0 & 0 \\
& 50 & 1,0 & 0 & 0,5 \\
& 10 & 0 & 0 & 0 \\
& Kontrol positif & 15,0 & 12,0 & 13,5 \\
& Kontrol negatif & 0 & 0 & 0 \\
\hline \multirow{5}{*}{ Isolat F2.2.2 } & 100 & 0 & 0 & 0 \\
& 80 & 0 & 0 & 0 \\
& 60 & 0 & 0 & 0 \\
& 40 & 0 & 0 & 0 \\
& 20 & 0 & 0 & 0 \\
& Kontrol positif & 13,0 & 14,0 & 0 \\
\hline
\end{tabular}

Dari tabel 2 dapat dilihat bahwa yang memiliki aktivitas antibakteri terhadap Escherichia coli adalah ekstrak aseton daun perepat. Ekstrak memiliki aktivitas antibakteri tertinggi pada konsentrasi 1000 ppm diikuti $500 \mathrm{ppm}$ dan $50 \mathrm{ppm}$ dimana ketiganya masih tergolong lemah. Secara umum, semakin besar konsentrasi sampel uji maka semakin banyak jumlah zat aktif yang terkandung didalamnya sehingga semakin tinggi kemampuannya dalam menghambat pertumbuhan suatu bakteri (Ajizah, 2004).
Isolat F2.2.2 menunjukkan tidak adanya aktivitas antibakteri terhadap Escherichia coli yang dapat dikarenakan konsentrasi isolat uji tidak cukup mampu untuk merusak lapisan dinding sel bakteri Escherichia coli (bakteri gram negatif) yang tebal sehingga menyebabkan komponen kimia yang bersifat antibakteri sulit untuk masuk (Jawetz et al., 1980). Escherichia coli yang merupakan bakteri gram negatif relatif mengandung lebih banyak lipid pada lapisan dinding selnya sehingga menyebabkan senyawa terpenoid yang bersifat larut dalam lipid akan lebih mudah menembus dinding 
selnya (Rosyidah et al., 2010). Penelitian sebelumnya telah melaporkan lupeol aktif sebagai antibakteri terhadap Escherichia coli namun dalam konsentrasi yang tinggi (100 $\mu \mathrm{g} / \mathrm{mL}$ ) (Musa et al., 2018). Lupeol juga menunjukkan aktivitas antibakteri terhadap bakteri lain seperti Pseudomonas aeruginosa, Staphylococcus aureus (Musa et al., 2018), Enterococcus faecalis (Wal et al., 2015) dan Bacillus subtilis (Suryati et al., 2011).

Senyawa triterpenoid lainnya yang memiliki aktivitas antibakteri terhadap Escherichia coli adalah arjunolic acid, asiatic acid, terminolic acid dan 6hydroxyasiatic acid (Djoukeng et al., 2005), taraxerone dan tricadenic acid (Ghosh et al., 2011), ergosta-4,6,8(14),22-tetraene-3-one,

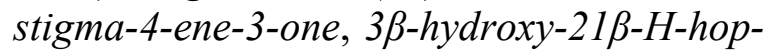
22(29)-ene dan sitosterol (Awolola et al., 2017).

\section{DAFTAR PUSTAKA}

Ajizah, A. 2004. "Sensitivitas Salmonella thypimurium Terhadap Esktrak Daun Psidium guavana L.”. Biosscientiae. Vol 1(1) : 31-38.

Awolola, G.V., H. Chenia., H. Baijnath dan N.A. Koorbanally. 2017. "Anti-adhesion Potential of Non-polar Compounds and Extracts from Ficus natalensis". Revista Brasileira de Farmacognosia. Vol 27 : 599-602.

Bell, C.E. 1997. Organic Chemistry Laboratory: Standard and Microscale Experiments 2nd Edition. Saunders College Publishing. San Diego.

Cowan, M. 1999. "Plant Product as Antimicrobial Agent". Clinical Microbiology Reviews. Vol 12(4) : 564-582.

Dachriyanus. 2004. Analisis Struktur Senyawa Organik Secara Spektroskopi. LPTIK Universitas Andalas. Padang.

Djoukeng, J.D., E. Abou-Mansour., R. Tabacchi., A.L. Tapondjou., H. Bouda dan D. Lontsi. 2005. "Antibacterial Triterpenes from Syzygium guineense (Myrtaceae)". Journal of Ethnopharmacology. Vol 101(1-3) : 283-286.

\section{KESIMPULAN}

Karakteristik spektrum UV isolat F2.2.2 menunjukkan serapan maksimum pada panjang gelombang $203 \mathrm{~nm}$ dan $212 \mathrm{~nm}$ yang merupakan ciri khas dari sistem ikatan rangkap $\mathrm{C}=\mathrm{C}$ terisolasi senyawa triterpenoid. Sedangkan, karakteristik spektrum FTIR isolat F2.2.2 menunjukkan isolat memiliki gugus $-\mathrm{OH}$, ikatan $\mathrm{C}-\mathrm{O}$, ikatan rangkap terisolasi, ikatan $\mathrm{C}-\mathrm{H}$ serta gugus gem dimetil yang menegaskan bahwa isolat F2.2.2 merupakan senyawa golongan triterpenoid triterpenoid yang diduga sebagai Lupeol. Ekstrak aseton daun perepat menunjukkan aktivitas antibakteri terhadap Escherichia coli. tertinggi pada konsentrasi 1000 ppm diikuti 500 ppm dan 50 ppm dimana ketiganya masih tergolong lemah. Sedangkan isolat F2.2.2 tidak menunjukkan adanya aktivitas antibakteri terhadap Escherichia coli.

Gandjar, I.G dan A. Rohman. 2018. Spektroskopi Molekuler Untuk Analisis Farmasi. Gadjah Mada University Press. Yogyakarta.

Ghosh, P., P. Chakraborty., A. Mandal., M.G. Rasul., M. Chakraborty dan A. Saha. 2011. "Triterpenoids from Schleichera oleosa of Darjeeling Foothills and Their Antimicrobial Activity". Indian Journal of Pharmaceutical Sciences. Vol 73(1) : 231-233.

Harizon., B. Pujiastuti., D. Kurnia., D. Sumiarsa dan Y. Shiono. 2014. "Triterpenoid Lupan dari Kulit Batang Sonneratia alba (Lythraceae)". Bionatura-Jurnal Ilmuilmu Hayati dan Fisik. Vol 16(1) : 25-29.

Hartini, V.A., K. Anam dan B. Cahyono. 2012. "Isolasi Senyawa Triterpenoid dari Daun Ketapang Kencana (Terminalia muelleri Benth) dan Uji Aktivitas Sitotoksik dengan Metode Brine Shrimp Lethality Test (BSLT)". Jurnal Kimia Sains dan Aplikasi. Vol 15(2) : 47-52.

Igoli, O.J dan G.I. Alexander. 2008. "Friedelanone and Other Triterpenoids from Hymenocardia acida". 
International Journal of Physical Sciences. Vol 3(6) : 156-158.

Jawetz, E., J.L. Melnick dan E.A. Adelberg. 1980. Review of Medical Microbiology. Fourteenth edition. Lange Medical Publication. California.

Latief, M., Nazarudin dan Nelson. 2014. "Skrining Bioaktivitas Beberapa Tumbuhan Mangrove Asal Kabupaten Tanjung Jabung Timur Provinsi Jambi”. Skripsi, Penelitan Fundamental Pedada.

Muharni. 2010. "Triterpenoid Lupeol dari Manggis Hutan (Garcinia bancana Miq.)". Jurnal Penelitian Sains. Vol 13(3(C)) : 13308-40 - 13308-45.

Musa, W.J.A., S. Duengo dan B. Situmeang. 2018. "Isolation and Characterization Triterpenoid Compound from Leaves Mangrove Plant (Sonneratia alba) and Antibacterial Activity Test". International Research Journal of Pharmacy. Vol 9(3) : 85-89.

Noor, Y.N., M. Khazali dan I.N.N. Suryadiputra. 2006. Panduan Pengenalan Mangrove di Indonesia. PHKA/WI-IP. Bogor.

Pratama, M.R. 2005. "Pengaruh Ekstrak Serbuk Kayu Siwak (Salvadora persica) terhadap Pertumbuhan Bakteri Streptococcus mutans dan Staphylococcus aureus dengan Metode Difusi Agar". Skripsi, FMIPA ITS, Surabaya.

Rosyidah, K., S.A. Nurmuhaimina., N. Komari dan M.D. Astuti. 2010. "Aktivitas Antibakteri Fraksi Saponin dari Kulit Batang Tumbuhan Kasturi (Mangifera casturi)". Alchemy. Vol 1(2) : 65-69.

Roth, J.H dan G. Blaschke. 1985. Analisis Farmasi. Gadjah Mada University Press. Yogyakarta.
Saad, S., M. Taher., D. Susanti., H. Qaralleh dan A. F. Izyani Bt Awang. 2012. "In Vitro Antimicrobal Actvity of Mangrove Plant Sonneratia alba". Elsevier, Asian Pacific Journal of Tropical Biomedicine. Vol 2(6) : 427-429.

Sahoo, G., N.S.S. Mulla., Z.A. Ansari dan C. Mohandass. 2012. "Antibacterial Activity of Mangrove Leaf Extracts Against Human Pathogens". Indian Journal of Pharmaceutical Sciences.

Siahaya, V.G., T. Moniharapon., M.N. Mailoa dan J.A. Leatemia. 2018. "Potential of Mangrove Apples (Sonneratia alba) as a Botanical Insecticide". Modern Applied Science. Vol 12(1) : 1-8.

Silverstain, R.M., G.C. Bassler dan T.C. Morrill. 1981. Penyidikan Spektrometrik Senyawa Organik, Edisi Keempat. Penerjemah Hartomo A.J. dan A.V. Purba. Erlangga. Jakarta.

Surya, S dan N. Hari. 2017. "Studies on Preliminary Phytochemical Analysis of Some True Mangrove Species in Kerala". International Journal of Research in Pharmacy and Pharmaceutical Sciences. Vol 2(3) : 15-17.

Suryati., H. Nurdin., Dachriyanus dan M.N.H. Lajis. 2011. "Structure Elucidation Of Antibacterial Compound From Ficus deltoidea Jack Leaves". Indo. J. Chem. Vol 11(1) : 67-70.

Wal, A., R.S. Srivastava., P. Wal., A. Rai dan S. Sharma. 2015. "Lupeol as A Magical Drug". Pharmaceutical and Biological Evaluations. Vol 2(5) : 142-151.

Yudasakti, P., T. Rahmadhani dan M. Nainggolan. 2014. Mangroves Siak dan Kepulauan Meranti. Energi Mega Persada. Jakarta. 